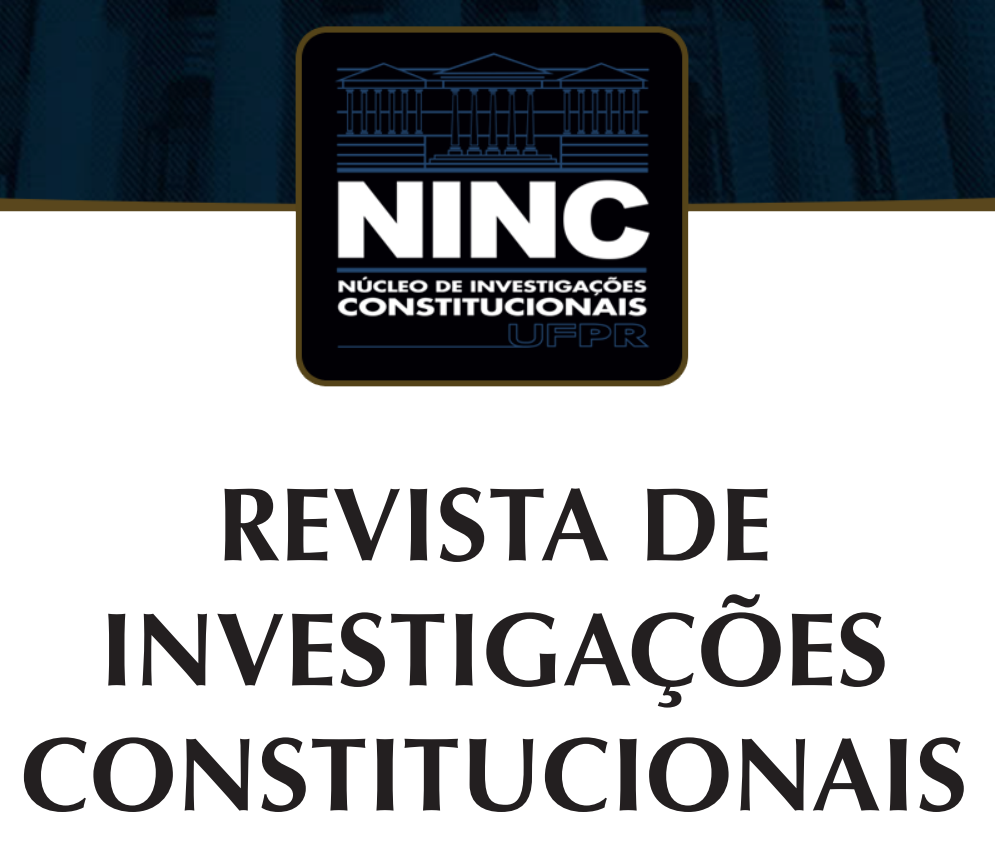

JOURNAL OF CONSTITUTIONAL RESEARCH

vol. 6 | n. 2 | maio/agosto 2019 | ISSN 2359-5639 | Periodicidade quadrimestral Curitiba | Núcleo de Investigações Constitucionais da UFPR | www.ninc.com.br 


\section{Anti-racism legislation in Brazil: the role of the Courts in the reproduction of the myth of racial democracy}

\section{Legislação antirracista no Brasil: o papel das Cortes na reprodução do mito da democracia racial}

MARTA RODRIGUEZ DE ASSIS MACHADO !, *

'Fundação Getúlio Vargas (Brasil) martarodriguezmachado@gmail.com https://orcid.org/0000-0002-8924-089X

MÁRCIA LIMA ", **

" Universidade de São Paulo (Brasil) mrlima@usp.br https://orcid.org/0000-0003-2923-8445 NATÁLIA NERIS DA SILVA SANTOS ", ***

" Universidade de São Paulo (Brasil) nerisnatalia@gmail.com https://orcid.org/0000-0002-3449-813X Recebido/Received: 06.11.2019 / November $6^{\text {th }}, 2019$ Aprovado/Approved: 29.11.2019 / November 29th 2019

Abstract

The goal of this paper is to analyze Brazilian anti-racism law in practice, assessing judicial response to cases of racial stigma and insult. We analyzed over 200 cases from 9 Brazilian states involving racial insults and racial disparagement in Brazilian courts of appeal. We find that the

\section{Resumo}

O objetivo deste artigo é analisar a aplicação da legislação antirracista brasileira, por meio de decisões judiciais em casos de estigmatização racial e insultos. Analisamos mais de 200 casos de insultos racistas e depreciação nos tribunais de justiça brasileiros. Descobrimos que o judiciário tende

Como citar esse artigo/How to cite this article: MACHADO, Marta Rodriguez de Assis; LIMA, Márcia; SANTOS, Natália Neris da Silva. Anti-racism legislation in Brazil: the role of the Courts in the reproduction of the myth of racial democracy. Revista de Investigações Constitucionais, Curitiba, vol. 6, n. 2, p. 267-296, maio/ago. 2019. DOI: 10.5380/rinc.v6i2.70080.

" Professor at the Getulio Vargas Foundation School of Law (São Paulo-SP, Brasil) and Senior Researcher at the Brazilian Center of Analysis and Planning (CEBRAP). PhD, Master of Laws and Bachelor of Laws degree from the University of São Paulo. E-mail: martarodriguezmachado@gmail.com.

** Professor at University of Sao Paulo (São Paulo-SP, Brasil) and Researcher at the Center for Metropolitan Studies at the Brazilian Center of Analysis and Planning (CEM - CEBRAP). PhD from the Federal University of Rio de Janeiro. E-mail: mrlima@usp.br.

*** PhD Candidate at University of Sao Paulo (São Paulo-SP, Brasil) and researcher at the Law and Democracy Center at CEBRAP. Master in Law and Development at the Getulio Vargas Foundation School of Law. E-mail: nerisnatalia@gmail.com. 
judiciary tends to downplay the importance of insult and stigma, often dismissing cases or lowering penalties. This judicial treatment conflicts with the evidence that racial insults are prevalent in society and serve to maintain racial hierarchies. While the judiciary appears to be enforcing anti-discrimination law, the actual decisions show that the legal system fails to recognize and deal with the real dynamics of Brazilian racism thereby reinforcing the myth of Brazil racial democracy.

Keywords: anti-racism legislation; Brazil; courts; racial democracy; racism. a minimizar a importância de insultos e estigmas, com julgamentos de não provimento de recursos ou diminuindo sanções. Esse tratamento judicial conflita com as evidências de que insultos raciais são prevalentes na sociedade $e$ servem à manutenção de hierarquias raciais. Enquanto o judiciário parece estar promovendo a aplicação da legislação antirracista, as decisões de fato mostram que o sistema jurídico falha no reconhecimento e no enfrentamento das reais dinâmicas do racismo brasileiro, reforçando o mito da democracia racial brasileira.

Palavras-chave: legislação antirracista; Brasil; cortes; democracia racial; racismo.

\section{CONTENTS}

1. Introduction; 2. Stereotypes and racial insult; 3. The disputes for the creation of an anti-racism legislation in Brazil; 4. The dilemmas of enforcement: what happens when racism reaches the Courts; 4.1. Racial insult as the main issue arriving to the Judiciary; 4.2. The procedural way out; 4.3. When the judge analyses the merits of the case; $\mathbf{5}$. Conclusion: how Courts fail to recognize Brazilian racism; $\mathbf{6}$. References.

\section{INTRODUCTION}

The purpose of this article is to analyze how the legal mechanisms to combat racism are operating in Brazil and to highlight some of their main obstacles considering the social dynamics of stigma and racial insults. It analyzes the application of the anti-racist criminal legislation by the Courts, based on data from an empirical research conducted from 1998 to 2010 in Courts of Justice of 9 Brazilian states. Our argument is that there is a difficulty in reconciling the categories of the law and the way in which they are being interpreted by the Courts with concrete dynamics of race relations in which subtle acts of discrimination and the use of racial insults prevail in everyday situations. For this reason, the Brazilian justice system fails to communicate the blameworthiness of a large number of racist conducts that pass through it. This has a perverse effect in so far as it denies these racist acts making them invisible and in turn reinforces the racial democracy myth.

As is widely known, conceptions regarding race as well as its hierarchy's date back to the 19th century, the period in which a scientific doctrine was utilized to biologically explain social differences related to racial categories. Although the scientific legitimacy of this idea regarding race has fallen into disuse, the mechanism of legitimization of hierarchical differences between races persists relying on other ideologies, with racial stereotypes being the main mechanisms in the maintenance of this ideology'.

1 BANTON, Michael; MILES, Robert. Racism. In: CASHMORE, Ellis. Dictionary of Race and Ethnic Relations. 3. ed. London/New York: Routledge, 1994, p. 309. 
Thus, we can still talk about racism in reference to any form of explanation and justification for differences, preferences, privileges and inequalities between human beings, based on the idea of race, culture, or ethnicity. The word racism refers to doctrine or ideology that sustains inequality, but also to practices and mechanisms that operate at the individual and societal level to maintain disadvantage of certain groups from an economic, political, social and cultural perspective. These mechanisms - that are reproduced daily - act by the systematic undermining of certain characteristics of individuals, by maintaining their low self-esteem and by reproducing prejudice in relation to them².

In the face of diverse manifestations of this phenomenon, an attempt to address racism through law involves decisions on what do we want to be addressed by the legal system. Legal systems can deal with racism in different ways and with a variety of consequences. Racism can be read in different levels - collectively, institutionally or individually; through different public policies rationale (individual responsibility, collective responsibility, structural changes, affirmative action) and it can mobilize different areas of the legal system (constitutional law, torts, criminal law etc). Legal categories also differ. While in countries like the USA the category of hate speech seems to be articulated more broadly ${ }^{3}$, without losing a disputable nature 4 . In Brazil, the legal conceptual battles are dealing with the concepts of racism, racial discrimination and racial insult, mainly articulated through individual criminal liability. Individual criminal liability depends on the process of interpreting and applying criminal law, criminal procedural law and the general criteria developed by legal doctrine to consider if an individual's conduct is a crime (legality, intent, negligence, blameworthiness). One of the aims of this article is to show that the interpretations judges offer about criminal procedural norms, standard of proof and intent will make the difference in the reach of an antidiscrimination policy. Subsequently, it will define what will be considered racism or not according to the Brazilian legal order.

Brazilian anti-racism policy has been guided primarily based on criminal laws for quite a long time. The first anti-discrimination law was sanctioned in the 1950s (Afonso Arinos Act). The subject gained constitutional status in 1988, was regulated in 1989 by means of the Caó Act and has undergone some amendments since then. The history of this legislation, however, is permeated by dissatisfaction with its application and the persistence of racism in Brazilian society is viewed as evidence of its inefficacy.

In the following sections, we will explore the mechanisms of racial stigma and the sociological role of racial insults in Brazilian society (2). Later on, in addition to

2 GUIMARÃES, Antonio Sérgio Alfredo. Preconceito e discriminação: queixas de ofensas e tratamento desigual dos negros no Brasil. 2 ed. Editora 34, 2004, p. 215-217.

3 DELGADO, Richard; STEFANCIC, Jean. Understanding words that wound. Boulder: Westview Press, 2004.

4 BUTLER, Judith. Excitable Speech: A politics of the performative. New York, London: Routledge, 1997. 
presenting a brief history of anti-racism legislation (3), we analyze cases of racism that went to the Brazilian courts and their results (4). Understanding the rationale of the Law and the judge's interpretations of it and confronting them with the social mechanisms of operation and reproduction of racism will enable us to come to some conclusions about the inability of the justice system to recognize the dynamics of Brazilian racism.

Although we will not discuss all aspects of Brazilian racial dynamics in this text, we want to note that this diagnosis of the justice system's low performance in the enforcement of anti-racism legislation happens in a more general environment where racial inequality is reproduced. There are also other intersections of the justice system and structural racism that we will not address now, such as the selectivity of the criminal law system, racial police profiling, police brutality etc. On the other hand, we also want to acknowledge that to understand the persistence of racism and the reality of brutal racial inequalities in Brazil we should not only bear in mind the flaws in the implementation of anti-racism legislation, but also criticize the design of the public policy itself. In the last section (4), we will briefly reflect on the limitations of the punitive model.

\section{STEREOTYPES AND RACIAL INSULT}

Stereotypes and racial insults are mutually reinforcing and are an effective mechanism that explains the persistence of racial inequality in daily life. The performativity of racist discourse is described by Butler as the following ${ }^{5}$ :

Racist epithets not only relay a message of racial inferiority, but that 'relaying' is the verbal institutionalization of that very subordination. Thus, hate speech is understood not only to communicate an offensive idea or set of ideas but also to enact the very message it communicates: the very communication is at once a form of conduct

In this sense, as we will describe in this session, while stereotypes justify subordination, racist discourses reinforce the available racial stereotypes with a performative effect - it proclaims racial inferiority at the same time in which it exerts the effect of subordination.

Stereotypes are elements of differentiation and, therefore, create identity by contrast $^{6}$. The possession of an attribute becomes a differential in terms of the expectations and compromises of an individual's everyday relations with those considered as "normal". In terms of its racial aspect, stigma is symbolic, considering the fact that skin color is neither a physical disability nor a scar. The individual "racially" stigmatized is, in Goffman's terms, discredited, with a characteristic that evidently and immediately marks them ${ }^{7}$.

\footnotetext{
BUTLER, Judith. Excitable Speech: A politics of the performative. New York, London: Routledge, 1997, p. 72. LIPPMANN, Walter. Public opinion. New York: Harcourt, 1922.

ERVING, Goffman. Stigma: Notes on the management of spoiled identity. New York: Simon \& Schuster Inc, 1963.
} 
Racial stereotypes operate in the construction of a racialized place in Brazilian social structure, acting as a stigma. Although the construction of racial stereotypes is present regardless of the social position occupied by black individuals, it is important to understand how it interacts with class and social spaces. Nogueira ${ }^{8}$ developed a study that demonstrates how racial stereotypes have influenced black people's access to jobs. In this study the author sent job applications to more than two hundred advertised jobs. The interviewees felt that the preference for white employees was "very natural". The majority of responses involved negative remarks about blacks to justify their choice. Fear of being robbed by blacks, stereotyping them as having a lack of hygiene, disobedience, indiscipline, inadequacy in dealing with children, bad smell and laziness were some of the justifications cited. Appearance was also used considerably as a justification for not choosing black candidates such as the response that whites are chosen "because when serving at the table, a white person looks better". For those who preferred employees of color, stereotypes also remained present. The justifications were that blacks are more obedient and obliging in their duties, are stronger, more submissive and have simple needs.

Lima $^{9}$ showed how racial stereotypes reflect the social positions of black people in Brazilian society, with powerful consequences in the labor market. They operate to determine in which fields black people can achieve recognition and success - in general, as artists, musicians and soccer players. What are the areas of employment in which they are "prohibited?" Racial stereotypes operate to strengthen a type of mobility and demarcate the space where blacks can stand out while also reducing the range of possibilities to be occupied by these individuals. The "place" of blacks in the labor market is characterized by less prestigious occupations, low schooling and low income, with jobs that historically focus on domestic work for women, and on manual labor for men.

Racial stereotypes limit the social and economic possibilities for black people at the same time feeding on existing prejudice and reinforcing it. The social representations of blacks as not qualified, lazy, disorganized, violent, dirty, animals, criminals are mostly inherited from slavery and define the social imagination of both whites and blacks and justify the exclusion of blacks from certain social and professional positions.

Other studies have sought to more profoundly examine how racial stereotypes intertwine with situations of racial discrimination. The classic Oracy Nogueira's investigation, written in the 1950s, developed a comparative analysis of the system of color classification in Brazil and in the United States. A highlight of his comparison is the distinction between prejudice of mark and prejudice of origin. The first, which prevails

8 NOGUEIRA, Oracy. Tanto preto quanto branco: estudo de relações raciais. São Paulo: T.A. Queiroz, 1985.

9 LIMA, Márcia. Serviço de branco, serviço de preto: um estudo sobre cor e trabalho no Brasil urbano. 2001. Tese (doutorado em sociologia) - Programa de Pós-graduação em Sociologia e Antropologia, IFCS-UFRJ, Rio de Janeiro, 2001. 
in Brazilian society, refers to physical phenotypic characteristics; the term color is used more than race, the acceptance of appearance is marked by a gradient of color based on being lighter or darker. The second type of classification, typical of American society, would be marked by the "one drop rule", less miscegenation and bipolar racial categories (black and white). His conclusions demonstrate that in Brazilian society, in which there is the prejudice of mark, the explicit situations of conflict are more sporadic, maintaining differentiation and rejection with very subjective variations. Prejudice has an ambiguous character and coexists within friendships between whites and blacks. What is formed, then, in terms of ideology, is an assimilationist society, which provides a greater probability of ascension to those who have phenotypes increasingly closer to whites who are the reference. In this context, we do not see clearly a segregationist ideology and a collective reaction towards racial discrimination.

Guimarães says that the absence of explicit racial segregation - what has been called both by the sociological thinking ${ }^{10}$ and by the common sense - racial democracy enabled the development in Brazil of a "racial etiquette" in which blacks are classified socially by explicit social markers such as color, clothing, and way of speaking and behaving, but the way blacks are treated racially is masked ${ }^{11}$. Segregation also is subtle, disguising racial grounds under the idea of "good appearance", occupational ground ("service elevators"), title of property ("private property" or "exclusive places for owners"); or is still hidden under technical or cultural motivation (school merits, preference of clientele, qualification) ${ }^{12}$. Racism operates by means of this social etiquette as an element that restricts individual freedom in free circulation in public places, in the consumption of goods and services, in employment and in the professional arena.

\footnotetext{
10 In the sociological debate, we point to the important and influential interpretation of Gilberto Freyre's Brazilian cultural construction of miscegenation, which he considered a positive thing. "Brazilianness" was for him conceived as a result of the productive fusion of antagonistic cultures, arranged in a hierarchy in which the opposites complement each other harmoniously. In his words, "European culture is put in contact with the indigenous, softened by African oil". Culture was, therefore, shown as the locus of a resolution of antagonisms. By resolving antagonisms, this characteristic would be a great virtue, making Brazil a country where there were no racial differences because of one unified national culture making it a racial democracy - see FREYRE, Gilberto. Casa Grande e Senzala: formação da família brasileira sob o regime da economia patriarcal. 29 ed. Rio de Janeiro: Record,1994. This idea started to be confronted by Roger Bastide and Florestan Fernandes in the 1950's in their book Relações raciais entre brancos e negros em São Paulo (Racial relations between whites and blacks in São Paulo), published in 1955. Their research results challenged the image of a racial democracy, pointing to the extreme inequality that existed between white and black people. See also the classic work where he dedicates one of his chapters to criticizing the idea of racial democracy: FERNANDES, Florestan. A integração do negro na sociedade de classes. São Paulo: Cia. Editora Nacional, 1965. See also: BASTIDE, Roger; FERNANDES, Florestan. Relações raciais entre negros e brancos em São Paulo. São Paulo: Editora Anhembi, 1955.

11 GUIMARÃES, Antonio Sérgio Alfredo. Racismo e anti-racismo no Brasil. 1997. Tese (livre docência em sociologia) - FFLCH, Universidade de São Paulo, São Paulo, 1997.

12 GUIMARÃES, Antonio Sérgio Alfredo. Racismo e anti-racismo no Brasil. 1997. Tese (livre docência em sociologia) - FFLCH, Universidade de São Paulo, São Paulo, 1997, p. 36.
} 
More recently, since Brazilian society started to increasingly allow the presence of black people in places that historically were frequented mainly by white people, there are more cases of explicit racism than in the past. Also, the public debate about race has increased since the beginning of the 2000's when the Brazilian government started to address public policies to challenge racial prejudice and racial inequalities ${ }^{13}$. However, it is still difficult to see a strong collective reaction against racial discrimination.

Lamont et al. ${ }^{14}$ conducted a substantial comparative investigation in Brazil (Rio de Janeiro), United States (Chicago) and Israel (Tel-Aviv). The primary purpose of the investigation was to understand how racialized minorities responds in confronting racism. According to the authors, although Brazil and the United States present race as a primary basis of groupness, their group dynamic differs a lot: Brazilian racial groupness can be characterized as ambiguous, and the American is strong; as well as the meaning of identity is weak for Brazilians and strong for Americans. So, the image of blurred characterization of racial groups and racism is still working in comparative research. However, the study identifies that racial stereotypes work in the same way. Blacks are identified with low-class status, black men are threatening, and discrimination largely based on race are common in both countries. Gladys Mitchell-Walthour ${ }^{15}$ finds high level of black racial groupness in Salvador, Sao Paulo, and Rio de Janeiro and this group identity is largely due to experiences of racial discrimination.

Against this background, in what contexts are there racial insults? Racial insults are episodic manifestations that reproduce and reinforce racial stereotypes. They appear in two typical and opposite situations: in jokes and in conflict. While both present themselves in similar forms, with emphasis on disqualification and on the animalization of the black person, the joke is a form of "diluting" the tension without failing to mark the difference. On the other hand, racial insults that manifest themselves in situations of conflict break the pact of accommodation of racism. It is not a coincidence that conflictive racial insult situations correspond to the great majority of cases taken before the judiciary. It makes racial conflict visible and the victim is mobilized to engage the legal system ${ }^{16}$.

Understanding the context in which racial insults are uttered - both in jokes, as in the different types of conflictive situations - allows you to see beyond the meaning of words such as - animalization, lack of hygiene and morality, etc. and forces

\footnotetext{
13 LIMA, Marcia. Desigualdades raciais e políticas públicas: ações afirmativas no governo Lula. Novos Estudos CEBRAP, São Paulo, n. 87, p. 77-95, jul. 2010.

14 LAMONT, Michèle et al. Getting respect: responding to stigma and discrimination in the United States, Brazil and Israel. New Jersey: Princeton University Press, 2017.

15 MITCHELL-WALTHOUR, Gladys. The Politics of Blackness: Racial Identity and Political Behavior in Contemporary Brazil. New York: Cambridge University Press, 2018.

16 In our empirical research of legal cases, we found only one case - a song with offensive lyrics - which was in a gray area between a joke and conflict.
} 
you to examine the social dynamics that each utterance triggers. The insult performs a function in race relations. Its repetition creates a background which legitimizes the permanent discrimination and inferior position of black people. In the specific moment of its evocation, it has the strength to recreate social reality to degrade black people, reinforcing or reestablishing the defined social order.

This impetus, which becomes evident when we look more carefully at the cases and types of context in which they occur, is often disregarded in the analysis of judges who are mainly focused on the content of the offense or on the author's intention. The incomprehension of the performativity of racist discourse by Brazilian Courts, as we will see below, is expressed in the cases in which the racial aspect is disregarded to favor only the inter-subjective conflict; or in cases in which the Court does not recognize the author's racist intention.

\section{THE DISPUTES FOR THE CREATION OF AN ANTI-RACISM LEGIS- LATION IN BRAZIL}

Today in Brazil we have four kinds of behaviors defined as racist crimes: i) discrimination of treatment and refusal of assistance and access to establishments, employment or positions; ii) racial insult; (iii) the practice or public incitement (with or without using means of communication) of discrimination or prejudice which is a very open description and therefore with disputable coverage; iv) the display and circulation of the swastika. This regulation was a result of a long dispute of the Black movement trying to pass legislation and to reform the description of criminal conduct in order to give teeth to the law.

The demand for anti-discrimination legislation on the part of the Black movement in Brazil had already been expressed since at least 1945 and in a certain way, had already found some support backed by the Federal Constitution of 1946, which prohibited advertising spreading "prejudice of race and color". But the first criminal anti-racism law was motivated by an episode that gained international attention, when the American ballet dancer Katherine Dunham was not allowed to stay in a hotel in Rio de Janeiro because she was black. Soon afterwards, in 1951, Law no. 1390 was approved, given the name of the congressman that had proposed it - Afonso Arinos.

The Afonso Arinos Act classifies as misdemeanors a series of discriminatory conduct: a refusal by commercial establishments, educational establishments, leisure establishments, sports, restaurants or accommodation to assist or serve a customer due to prejudice against race or color; inhibit access to employment in a public or private company due to prejudice against an individual's race or color; inhibit access to a job in the civil service or the armed forces due to prejudice against an individual's race or color. In 
Brazil, misdemeanors are considered a less important offense than a crime, punishable with a fine, loss of job or simple prison sentence, ranging from 15 days to 1 year.

The episode involving the ballet dancer and the new law had an ambiguous reaction amongst black militants: there were those who considered the law a victory - which would oblige whites to accept, albeit coercively, black people in their establishments - and others that saw it as a merely symbolic measure impossible to be applied against the dominant classes, which sought only to not address the struggles and social demands of black people ${ }^{17}$.

Moreover, the criticisms about the effectiveness of the application of that law were continuous. A few years after its promulgation, it was said that nobody had ever been arrested on the basis of it and questioned the difficulty of proving prejudice. In employment advertisements, for example, the requirement of "good appearance" invariably referred to the non-acceptance of black candidates, but such masked prejudice was not detected by the justice system. Among criticisms of the law, it was pointed out that the conduct described therein were very specific and did not reflect the discriminatory practices and that the fact that the discriminatory act is considered a criminal misdemeanor, and not a felony minimized its severity ${ }^{18}$.

The distance between legal mentions to formal equality - maintained also in the military Constitution of 1964 - and the reality of race relations in Brazil began to be more strongly denounced with the articulation of the Black movement at the end of the 1970s with the re-democratization of the country and the emergence of the Movimento Negro Unificado (Black Unified Movement). In 1979, the Black Unified Movement held the symbolic burial of the Afonso Arinos Act, denouncing its inefficacy ${ }^{19}$.

There were a number of reports of the inefficiency of the law and of people who suffered discrimination and found no support from the justice system. One important black activist was Abdias Nascimento who in a draft bill sought to revoke the Afonso Arinos Act and forecasted racism as a crime against humanity is emblematic in this sense $^{20}$ :

The Afro-Brazilian community has been crying out, for many years, for the withdrawal of the so-called Afonso Arinos Act, i.e. Law no. 1.390/51, and its replacement by a legal

\footnotetext{
17 FULLIN, Carmen Silvia. A criminalização do racismo: dilemas e perspectivas. 1999. Dissertação (mestrado em Sociologia) - FFLCH, Universidade de São Paulo, São Paulo, 1999.

18 NASCIMENTO, Abdias do. Combate ao racismo: discursos e projetos. Brasília: Coordenação de Publicações Câmara de Deputados, 1983.

19 FULLIN, Carmen Silvia. Direito e Racismo: Observações sobre o alcance da legislação penal antidiscriminatória no Brasil. Revista da Faculdade de Direito de São Bernardo do Campo, São Bernardo do Campo, v. 6, n. 2, p. 21-35, 2000.

20 Draft Bill 1661, of 1983, available at: NASCIMENTO, Abdias do. Combate ao racismo: discursos e projetos. Brasília: Coordenação de Publicações Câmara de Deputados, 1983.
} 
device that actually punishes, as determined in art. 153, § 1, of the Brazilian Constitution, prejudice and discrimination of color and race. The present draft bill, defining such discrimination as a crime against humanity, as the Nazi anti-Judaism and the apartheid regime in South Africa were defined previously, is not only of an MP, but of the entire black community of Brazil, whose members and spokesmen unanimously agree on the ineffectiveness of the so-called Afonso Arinos Act. The first reason is an elementary simplicity: the existence of the said law in any form, from any perspective, was effective in decreasing the practice of racism in our country. Every day, we are faced with facts of discrimination and racial prejudice that never reach the courts of justice or whose processes are filed under one pretext or another or a legal subterfuge. [...] Wielding the "Afonso Arinos Act", which considers racism a misdemeanor (and not a crime, like many believe), is an expedient that the small black middle class has already abandoned - even because in over thirty years of existence (the law is from 1951), no racist has ever been condemned. In fact the "Afonso Arinos Act" does not meet our racial reality because it is absolutely unsuitable to the circumstances in which discrimination occurs in Brazil.

Based on this perception, the proposal - supported by the Black movements tried to adopt a new law that describes the crime of discrimination, with a more generic description: "the practice of any acts or omissions which, explicitly, covertly or empirically, applies differentiated treatment, offering or causing material or moral damage to persons belonging to human groups historically subject to identification according to the racial, ethnic or epidermal color criteria." The bill also stressed that it was "unnecessary to prove the explicit statement, intentions, opinions or subjective attitudes of the offender", seeking to minimize the difficulty of proving the intention. This bill was never approved and the demand for a criminal law continued being articulated, now in the context of the National Constituent Assembly.

That moment in the history of Brazil began the possibility of communication between civil society and the State, since it is the landmark of the transition from the dictatorial regime to democracy. Different social movements sought to focus on the process of drawing up the new constitutional text forwarding its demands to parliamentarians. For the Black movement, that moment represented the possibility of addressing the State denouncing its omission in relation to the black population ${ }^{21}$ and presenting proposals for policies to minimize Brazilian inequalities based on race.

21 In 1988, year of the promulgation of the new constitutional text, various state bodies and the Brazilian media were engaged in promoting events in commemoration of the Centenary of the Abolition of Slavery, which the movement strongly fought by promoting acts that denounced the farce of abolition and the persistence of inequities in Brazilian society. 
The will to influence and participate in the process of drafting a new constitution is very evident in the speech of the activist Hamilton Cardoso ${ }^{22}$ in the wake of the transition:

Until now the Brazilian Constitutions have not been more than talks between whites. The elites and the military have stuck to the old proverb: "May they, the whites, understand each other". And they did. However, things can no longer be so. The next constituent assembly will have to include, in the new social pact, the understanding of what black and indigenous people think the organization of society should be. The conversation will be democratic, multiracial and popular.

Concerning the denouncement of inequalities, Lélia Gonzalez, important black feminist leader, addressing the constituent parliamentarians during a public hearing, stated:

All who are here present have a great responsibility, especially those who actually do not defend their personal interests or those of their dominant class. To these we do not have much to say and we do not mean much, but to those who actually have a project for the construction of a fair and equal society, where the principle of equality actually materializes, to those we address, we must unite, we need to stand hand in hand. (...) we join those Constituents, those who are effectively representatives of the Brazilian people, to join us, who are sensitive to our proposals, to our denunciations, to our demands, because, I repeat, it is not with the black woman in prostitution; it is not with the black man being arrested every day by a policeman who considers him, above anything else, a suspect, it is not with discrimination in the labor market; it is not with the distorted and undignified presentation of the image of blacks in the media; it is not with pedagogical theories and practices that forget, and omit the History of Africa and of black and indigenous populations in our country, it is not with this that we are going to build a Nation ${ }^{23}$.

As we noted, inequalities of various orders were exposed, and concerning them, demands that referred to education, health, police violence, culture, work and access to land were added to the appeal already articulated in the public sphere about penalizing racism. On this issue, what concerns us more for the purposes of this study, activists justified the need for its insertion in the text for the following reasons: the criminalization of racism would unveil the racial democracy myth in so far as it could be denounced and penalized. In addition, they believed that the denouncement

22 CARDOSO, Hamilton. Isso é conversa de branco. Lua Nova: Revista de Cultura e Política, São Paulo, v. 2, n. 3, p. 13-19, dez.1985, p. 13.

23 SANTOS, Natália Neris da Silva. A voz e a palavra do Movimento Negro na Assembleia Nacional Constituinte (1987/1988): Um estudo das demandas por direitos. 2015. Dissertação (Mestrado em Direito) - Escola de Direito da Fundação Getulio Vargas, São Paulo, 2015, p. 84. 
performed systematically would fulfill a role not only of awareness of society, but also for the mobilization of blacks ${ }^{24}$.

The final text of the 1988 Constitution acknowledged certain anti-racism demands - especially those more general and with less redistributive effect ${ }^{25}$ - but inscribed expressly that "the practice of racism" constitutes "a non-bailable crime without statutes of limitation, subject to imprisonment". This constitutional declaration was considered a victory of the Black movement, as we noted in the speech of the black constituent Benedita da Silva ${ }^{26}$ :

It was in 1988 that the expression of equality and prohibition of discrimination were most emphatic than in any other document. The historically invisible Brazilians were protagonists in the construction of the text of the Magna Carta.

The promulgation of the new Constitution performed a symbolic effect, in declaring expressively the non-acceptance of racism in the democratic social pact. Henceforth, it would be up to the infra-constitutional legislation to define what is meant by the practice of racism and regulate the terms of application of a criminal legislation to this issue.

This happened in the following year by means of Law no. 7.716, known by the name of the Member of Parliament (MP) who proposed it, Carlos Alberto Caó. The Caó Act has defined crimes subject to penalty of 1 to 3 years of imprisonment for conduct similar to those described by the Afonso Arinos Act which are: prevent or hinder access; refuse or prevent access to a commercial establishment, teaching establishment, restaurant, of accommodation, public transport, a place in public administration or in the armed forces; deny employment, prevent career advancement, provide differentiated treatment at work; prevent access to social entry in public or residential buildings; and prevent or hinder the marriage or family and social coexistence, due to prejudice of race or color. The new law did not address one of the main criticisms of the Black movement to the Afonso Arinos Act which was that the description of criminal conduct did not correspond to the way racism appears in society since it focuses on acts of explicit segregation while Brazilian racism operates in much more subtle ways.

\footnotetext{
24 SANTOS, Natália Neris da Silva. A voz e a palavra do Movimento Negro na Assembleia Nacional Constituinte (1987/1988): Um estudo das demandas por direitos. 2015. Dissertação (Mestrado em Direito) - Escola de Direito da Fundação Getulio Vargas, São Paulo, 2015.

25 Like mentions to the equality principle. To check to what extent such demands have indulged in in the Brazilian Federal Constitution, check: SANTOS, Natália Neris da Silva. A voz e a palavra do Movimento Negro na Assembleia Nacional Constituinte (1987/1988): Um estudo das demandas por direitos. 2015. Dissertação (Mestrado em Direito) - Escola de Direito da Fundação Getulio Vargas, São Paulo, 2015.

26 Testimony of the MP during the Commemoration of 25 years of the Federal Constitution, available on: $<$ https://www.youtube.com/watch?v=azKNWwCbBak\&feature=youtu.be $>$.
} 
The following year, this law was reformed to include the practice, induction or incitement, by means of social communication or by publication, of discrimination of race, religion, ethnic or national origin, under penalty of reclusion from 2 to 5 years. The proponent of the amendment affirmed that Law 7.716 was concerned with establishing the punishment for the "routine practices of discrimination of race and color", but maintained not punishable the conduct of the "preaching, in any form, of racism and discrimination or prejudice of religion, ethnic or national origin, either through publication of any nature, whether through the spoken or televised press."

In 1994, under the threat of the same punishment, another conduct would be introduced in the legal order as a crime: the manufacture, commercialization, distribution or dissemination of symbols, badges, ornaments, emblems or propaganda that use the swastika, for purposes of dissemination of Nazism. The author of the proposal, in his justification, points out the concern with the expansion of fascist Nazis in the country - expressly stating the skin heads and the white powers - that "adopt the undeniably racist posture when they violently put themselves in a position of confrontation against Jews, people from the Northeast region, black people and homosexuals".

In 1997, a wider reform of the law was carried out by MP Paulo Paim, who maintains a strong dialogue with the Black movement. He kept the second above mentioned crime and changed the first excluding the requirement of dissemination in the media. The crime is then described as: "to practice, induce or incite discrimination or prejudice of race, color, ethnicity, religion or racial origin", under penalty of imprisonment from 1 to 3 years. The use of the media becomes a more serious form of this conduct thus punished with sentences from 2 to 5 years.

The 1997 law also introduces racial insult as a crime. In fact, it creates the qualified form of disparagement, the one that uses elements referring to race, color, ethnicity, religion or origin, under the penalty of reclusion from 1 to 3 years. Racial disparagement brings a much more serious penalty than the general crime of "simple disparagement", to be punished by imprisonment of 1 to 6 months. The ratio of this difference would be that a general disparagement constitutes only an offense to the dignity or the decency of a single person and the racial disparagement is a form of prejudice to the whole group. In the proposal for a legislative change, two years before, Paulo Paim pointed to the need of updating Law 7.716, "to attack impunity" and "to eliminate, in all forms possible, the public manifestation of odious prejudice". He also refers to the need to curb practices of racism that show themselves in the form of crimes against decency, honor and dignity: "the stereotype, used very often in these behaviors, is a form of prejudice because this is a flippant, ironic, debauched expedient, with an accentuated component of contempt in describing someone".

The changes to the 1997 law reflect the dissatisfaction already articulated in the public sphere by Black movement activists, in particular by the organization SOS 
Racismo. Created in 1990, this organization has a strong presence in the legal field, offering services of guidance and legal assistance to victims of racism, in addition to developing an advocacy role with the Legislative bodies. Since the beginning of its operations, it began to denounce the insufficiency of anti-racism legislation in strength and the "lack of political will of the Judiciary Powers" concerning racial issues. One of its founders, Sueli Carneiro, made an assessment of the performance of the law and of the Judiciary in 1996. She points out as obstacles to the effectiveness of the law: the "precarious legal description of the crime of racism", explaining that "the legislation available does not cover all the situations of discrimination presented to SOS Racismo, since $80 \%$ of the cases presented are not included in the scope of the current anti-racism legislation"; "the neglect as to how racial discrimination is treated in Brazil, as if it were an irrelevant subject to the Judiciary; the difficulty of obtaining testimonies and to prove acts of discrimination"; and the "interest to disqualify the crime of racism, classifying it as simple disparagement or defamation, which in our view is a way of concealing the degree of incidence of racial discrimination in Brazil" ${ }^{\prime 27}$. This last point reveals the importance of racist insults as an impetus of perpetuating racism and explains the creation, in 1997, of the crime of racial disparagement, with a much stricter penalty than that of simple disparagement ${ }^{28}$.

\section{THE DILEMMAS OF ENFORCEMENT: WHAT HAPPENS WHEN RA- CISM REACHES THE COURTS}

Based on data from empirical research performed between 1998 and 2010 in the Courts of Justice of 9 Brazilian states (Acre, Bahia, Mato Grosso do Sul, Paraíba, Pernambuco, Rio de Janeiro, Rondônia, Rio Grande do Sul and São Paulo), we investigated how legislation was applied to these crimes by the Courts ${ }^{29}$. We analyzed a total of 200 decisions of appellate courts - all of which were available to the public on the electronic sites of such Courts. With respect to the collection of data in the open databanks of the

27 CARNEIRO, Sueli; CORRÊA, Sônia; ADORNO, Sérgio; OLIVEIRA, Eduardo H. P. de. Racismo e Discriminação. Cadernos de Pesquisa, n. 4, p. 59-95, Jun. 1996, p. 61-62.

28 The crime of racial disparagement faces a challenge as a recent change in 2009, by means of Law no. 12.033, which did not interfere with the content but with the procedure in the judicial system. The criminal prosecution of such crimes became the initiative of the Public Prosecutor's office, on condition of the authorization of the offended party (what is called in the Brazilian system a public criminal lawsuit conditioned on representation). Until this time, it was necessary that victims interested in suing their aggressors have a lawyer (since the lawsuit was of private criminal nature).

29 This work was the result of the research project "The public sphere and law in Brazil: A case study on decisions involving equality of race", developed in the Law and Democracy Research Group of the Brazilian Center for Analysis and Planning (CEBRAP) under the scope of the broader Project "Morale, Politics and Law: Autonomy and Critical Theory". The following researchers participated in the project - under the coordination of Marta Rodriguez de Assis Machado and José Rodrigo Rodriguez: Carolina Cutrupi Ferreira, Fabíola Fanti, Marina Zanatta Ganzarolli, Flávio Marques Prol, Renata do Vale Elias, Carla Araújo Voros, Natália Neris da Silva Santos, Gabriela Justino da Silva and Haydée Fiorino Soula. 
Courts of Justice, it is necessary to clarify that not all cases effectively judged by the courts are available online. Therefore, our empirical data is based on decisions available in public databanks, although it does not refer to all of the cases judged ${ }^{30}$. The selection of the 9 Courts was guided by two factors: the availability of judgments on their websites and the quality of the search engine. In addition, we sought to select Courts from different regions of Brazil in order to diversify the set of material analyzed. The longitudinal cut begins one year after the last amendment of the law. Decision-making ended in 2010, completing twelve-year coverage. Moreover, this decade was crucial for the transformations that occurred in the Brazilian anti-racist agenda that culminated in the approval of the Racial Equality Statute in 2010, which took seven years to be approved.

It is also worth noting that we are speaking of a set of decisions that have already been taken before the Courts, i.e. that have already overcome other important steps - the willingness of the victim to utilize the justice system, filing the case at a police station, the police inquiry, the Public Prosecutor deciding to sue, or the victim having access to a private attorney, and finally the elaboration of the appeal to the Courts.

This means that one cannot, from the studied set, make considerations about the representativeness of these cases in the Brazilian criminal justice system. On the other hand, although not representative, it is a relevant universe. The discoveries this corpus was able to provide were pertinent to our research purposes: we were interested in understanding the dynamics of law enforcement, the use of legal concepts and arguments, the obstacles and bottlenecks that operated to generate the general feeling of dissatisfaction with the law. The official data bank provided by the Courts - although incomplete and quite criticized with regard to its use for empirical research - was still able to confront us with some of the system's patterns of action, disputed issues, and the points at which the functioning of the system in the cases of these crimes proved problematic. These data thus helped us to understand the dynamics and the narratives of the Judiciary in relation to racial crimes and to clarify the criticisms that circulate in the public sphere about the enforcement of the law. ${ }^{31}$

30 According to our interviews with people responsible for the public databanks of each Court, we discovered that the criteria for entering data into the public databases were variable or even not identifiable in some Courts. In any case, we can say that we are working with all the cases that were available on public databases. As it is a research with no quantitative pretenses, we understand that the existence of such a lack of all available data does not influence its results. For more methodological information about the construction of the corpus of the research check - MACHADO, Marta Rodriguez de Assis; FERREIRA, Carolina Cutrupi e SANTOS, Natália Neris da Silva. Legislação antirracista punitiva no Brasil: Uma aproximação à aplicação do direito pelos Tribunais de Justiça brasileiros. Revista de Estudos Empíricos em Direito, vol. 2, n 1, p. 60-92, 2015.

31 Black activists have articulated various criticisms regarding the implementation of the law. Cf. SANTOS, Ivair Augusto dos. Racismo no Brasil não é criminalizado. [Entrevista concedida a] Luciana Abade. Jornal do Brasil, Brasília, 30 sep. 2009. Available on: https://revistaforum.com.br/blogs/mariafro/bmariafro-ivair-augusto-dos-santos-racismo-no-brasil-nao-e-criminalizado/. Access: Nov. 05, 2019; O RACISMO minimizado. Correio Braziliense, Opinião, p. 20, 13 oct. 2009. Available on: https://www2.senado.leg.br/bdsf/bitstream/handle/ id/43505/noticia.htm?sequence=1\&isAllowed=y. Access: Nov. 05, 2019; SILVA JÚNIOR, Hédio. A política de 


\subsection{Racial insult as the main issue arriving to the Judiciary}

The first feature that calls our attention regarding the set of cases that reached the Judiciary is that these involve, in their great majority, situations linked to verbal offenses with the use of racist insults. We only found three cases in which discriminatory actions (linked to explicit difference of treatment or segregation) were discussed - a case in which the defendant refused to sell a box of matches to the victim in a commercial establishment, stating that they would not sell it to a "black son of a bitch" (negro filho da puta), "black thief (criolo safado); a case in which the father prevented his daughter from dating a black boy with death threats, and another case of refusal of employment in which the hiring had been agreed and confirmed through an acquaintance, but when the victim turned up in person she was refused the job, and the owner shouted: "Not a black girl, not a black girl" (negrinha não, negrinha não). This result gives strength to the Black movements' argument that Brazilian racism does not operate through explicit acts of segregation and that racial insults are more frequent.

We also found only three cases involving public dissemination of racist ideas or incitement of violence. In the first of these $\operatorname{cases}^{32}$, the criminal act consisted of the creation and distribution of leaflets in a public street, preaching the discrimination of black people, homosexuals and Jews and inciting violence. Signed by members of the group Orgulho Branco (white pride), the leaflets contained phases like: "the savagery of black racists from Africa never ends"; "the Zionist manipulation of our children's minds"; "homosexuality threatens civilization, make your day better, make the life of a homosexual a living hell". The other case involved the group White Power, which posted more than 200 posters in public streets against quotas for blacks in universities ("today they steal your place in public universities. If you do not act now who will ensure they won't steal places in public employment examinations?"; “White Power fighting for our rights, no matter what happens"; "we must ensure the existence of our race and the future of our children") $)^{33}$. In the third case, ${ }^{34}$ the defendants gathered together for a pronouncement of a television program and made racist and discriminatory remarks against people from the Northeast, black people, and Jews.

All the other 194 cases related to racial insults, even if there was a dispute about how to qualify it legally - simple disparagement, racial disparagement or the practice

\footnotetext{
inclusão do negro é a penal. [Entrevista concedida a] Fernanda da Escóssia. Folha de S. Paulo, São Paulo, 09 jul. 2001. Available on: https://www1.folha.uol.com.br/fsp/brasil/fc0907200113.htm. Access: Nov. 05, 2019; SILVA JÚNIOR, Hédio. Quando a lei não sai do papel. [Entrevista concedida a] Andréa Barros. Época, Rio de Janeiro, 13 dec. 2010. Available on: http://revistaepoca.globo.com/Revista/Epoca/0,EMI193501-15518,00.html. Access: Nov. 05, 2019.

32 Criminal Appeal 70012571659, Rio Grande do Sul State Court.

33 Criminal Appeal 990.08.180555-3,São Paulo State Court.

34 Criminal Appeal 202.256-3/1, São Paulo State Court.
} 
or inciting prejudice. Although in the lower courts there was more controversy in how to legally classify a case related to racial insults, in the Courts we only found one case in which it was recognized that an insult of a racial nature would also be a form of "practicing or inciting prejudice". All other cases were classified either as racial disparagement or as simple disparagement, and many of them ended up not being recognized as crimes, for different reasons that we will analyze hereinafter.

From the report of the decisions there are, whenever possible, transcripts of the insults from the aggressor to the victim ${ }^{35}$. The association between black people and "monkeys" is the most common insult. Secondly, we find "dirty black ${ }^{36 " ~(n e g r o / a ~ s u j o / a), ~}$ "smelly negro" (negro/a fedida) or "pig" (porco/a), followed by "black bum (negro/a vagabunda) or "lazy negro" (negro/a folgada). Another attack frequently observed is "black rascal" (negro/a safado/a). Black women are also associated with "bitch" (cadela ${ }^{37}$ ) and have their sexuality denounced as "easy women" or "sluts" (biscates ou piranhas). Aesthetic attributes are also used as aggressions: "black girl with hard hair" (nega ${ }^{38}$ do cabelo duro), "black girl with the curly hair" (nega do cabelo encaracolado), "hairy black" (nega cabeluda). There are also common statements used to offend with the expressions that imagine blacks as outsiders and not workers: "black man's job" (serviço de preto); "black thief" (negro ladrão), "junkie" (drogado/a). In some cases, the insult is only limited to mention the race or color, assuming that its evocation alone already carries a negative content: "you black guy" (seu preto), "it could only be a black" (só podia ser preto), "little black woman" (negrinha).

We can see that the offensive expressions directed at black people tend to animalize them and associate them with lower standards of hygiene, aesthetics, ethics and sexuality. Racial insult is used as an instrument of humiliation whose "effectiveness lies precisely in establishing distance between the insulter and the insulted, relating them to the terrain of poverty, social anomie, of dirt and of animality"39.

Some discourse intersperse insults directed to the person insulted with more general discourse about the entire group, reinforcing their hierarchy as a subordinate

35 It is important to note that many decisions of appeal courts do not count on a detailed description of the facts and therefore in many cases relating to racial insults, we have not been able to access the content of the offenses. Most of the times the offenses are transcribed without citation of the original source. Thus, it is assumed that this has originated from the report given in the police report or even in the testimony of the parties and witnesses. We only considered the offenses in inverted commas, i.e. we disregarded mentions of offenses in the form of paraphrase by the rapporteur judge, so as to avoid interpretive distortions.

36 We used "black" and not the literal translation of the Portuguese word "negro", because the word in English has a much serious connotation and occupy a different vernacular place.

37 The original word in Portuguese is the female name of dog which has also the component of comparison with animals.

38 Nega is a slang for black woman usually not used in a respectful way.

39 GUIMARÃES, Antonio Sérgio Alfredo. O insulto racial: as ofensas verbais registradas em queixas de discriminação. Estud. afro-asiát., Rio de Janeiro, n. 38, p. 31-48, Dec. 2000. Available at: http://www.scielo.br/scielo. php?script=sci_arttext\&pid=S0101-546X2000000200002\&lng=en\&nrm=iso. Access: Nov 05, 2019. 
social group: "as the saying goes, the police, blacks, bitches and poor people are shit" (como diz o ditado polícia, preto, puta e pobre é uma merda), "blacks are worthless" (negros não prestam), "only whites should be able to enter the Military Police", "blacks aren't welcome here" (lugar de negro não é aqui), "blacks have no rights", "blacks shouldn't be allowed to live next door to us". In some cases, although there are not many, there is explicit incitement to violence: "blacks should die, killing one a day isn't much". And in some others, slavery is evoked: "blacks are blacks and should be slaves to whites" (negro é negro e tem que ser escravo de branco), "the place of blacks is in the Senzala (slave quarters) ${ }^{40 "}$ (lugar de negro é na senzala), "blacks should go to the trunk of a tree ${ }^{41}$ , because this race should not exist", (negro tem que ir para o tronco que esta raça não deveria existir).

\subsection{The procedural way out}

In order to understand the dissatisfaction of how cases are processed by the justice system we must look at a large number of cases that are dismissed at an early stage, without even analyzing the merit of that case. The processing of cases in the first instance up to an initial decision of conviction or acquittal is not smooth sailing. In many cases, the judges do not even start the criminal lawsuit (and the cases go to the Appeal Courts to challenge this decision); in others, the defense questions its filing in the second instance ${ }^{42}$. In Court, the most frequent decision (29.5\%) was to prevent the continuation of the case before a decision based on merit ${ }^{43}$. The question of a lack of evidence is also quite relevant and is responsible for a good part of the cases in which

40 The shared house where enslaved people lived during slavery.

41 Log in which slaves were tied to be physically punished during slavery time.

42 Among the decisions studied, we observed that 58.5\% (117 cases) refer to criminal appeals - i.e. cases that have reached a final verdict in the lower courts and are taken before the Court by impulse of one of the parties (Public Prosecutor or Defense) with the objective of having this decision reviewed. Secondly, in $21.5 \%$ (43 cases) of the cases we have appeals in the strict sense such that all appeals made against the decision of the judge of first degree who rejected the accusation, i.e. ceased to establish the criminal lawsuit against the aggressor. Finally, with the exception of some rarer cases of appeals or proceedings brought directly to the Courts, $15.5 \%$ (31 cases) refer to habeas corpus indicted by the defense seeking to end the criminal lawsuit against the aggressor. See: MACHADO, Marta Rodriguez de Assis; FERREIRA, Carolina Cutrupi e SANTOS, Natália Neris da Silva. Legislação antirracista punitiva no Brasil: Uma aproximação à aplicação do direito pelos Tribunais de Justiça brasileiros. Revista de Estudos Empíricos em Direito, vol. 2, n 1, p. 60-92, 2015.

43 The final verdicts of the Courts had the following profile: in $15 \%$ of the cases (30) the Court decided to reject the denouncement or complaint, against $8 \%$ (16) that decided to receive and indict the criminal prosecution; in $14.5 \%$ (29) decided for the preliminary denial of the lawsuit (denial of criminality, cancellation or annulment of the lawsuit), whereas in $8.5 \%$ (17) the decision was to progress. If we add the decisions not receiving the accusation with the termination of the lawsuit we have here a significant figure of $29.5 \%$ (59 cases) in which the case did not proceed to a decision based on the merit in the lower courts. We discuss these results in more detail in MACHADO, Marta Rodriguez de Assis; FERREIRA, Carolina Cutrupi e SANTOS, Natália Neris da Silva. Legislação antirracista punitiva no Brasil: Uma aproximação à aplicação do direito pelos Tribunais de Justiça brasileiros. Revista de Estudos Empíricos em Direito, vol. 2, n 1, p. 60-92, 2015. 
it was understood that the criminal lawsuit should not even be started (15 cases). In an important set of cases, rejection was due to a dispute over the legal qualification of the case, involving legal conducts with different tracks in the criminal justice system - racial insults (that are processed through private criminal lawsuit) or racial disparagement and incitement of racism (processed through public criminal lawsuit).

For example, conduct qualified as racist insult by the appellate court, had been qualified initially as practice or incitement of prejudice or as racial disparagement by the lower courts. The issue here is that, although the classification of the conduct is disputable, when the Court changes the qualification, it also concludes that the case should have started and followed through the justice system under a distinct procedural path. As a consequence, when the Court re-qualifies the case, it also prevents its continuation for procedural reasons - or the previous lawsuit is annulled, or the victim has already missed the time period required to initiate a private criminal lawsuit. We will not detail here all the legal and procedural issues that define the termination of the case ${ }^{44}$; but it is important to note that the dispute for the legal qualification of the case triggers a mechanism of procedural short circuit that is largely responsible for the termination of cases of racism. The redefinition of the legal classification given to the case by the Appeal Courts- from practicing racism to racial disparagement or simple disparagement - generates at that moment an irrational result: in so far as these latter offenses are processed through the private criminal lawsuit and not the public like the first, the victim should have filed the private criminal lawsuit in the term of 6 months after the incident; as they did not, evidently because their case was already progressing within the justice system as a public criminal lawsuit, the deadline had now been missed. With the reclassification of the case by the Court, the victim loses the right to sue their offender. This procedural imbroglio - difficult to make sense out of the formalistic juridical jargon - constitutes a significant way out of cases of racism from the judicial system. We can consider it a less costly way out, since judges justify this result on procedural bases and do not discuss conduct.

\subsection{When the judge analyses the merits of the case}

Considering the cases where the Court analyzed merit, there were 54 convictions ( $27 \%$ of cases) and 40 acquittals (20\%). The sentences were given for racial disparagement ( 27 cases $-55.1 \%$ ), crimes against honor in its simple form (14 cases $-28.7 \%$ ), practicing or inciting prejudice ( $8.1 \%$ - 4 cases), discriminatory behavior (6.1\% - 3 cases) and there was one case of contempt of a public servant. It is noteworthy that most

44 We explain this in more detail in MACHADO, Marta Rodriguez de Assis; FERREIRA, Carolina Cutrupi e SANTOS, Natália Neris da Silva. Legislação antirracista punitiva no Brasil: Uma aproximação à aplicação do direito pelos Tribunais de Justiça brasileiros. Revista de Estudos Empíricos em Direito, vol. 2, n 1, p. 60-92, 2015. 
cases relates to disparagement (racial or general) and few cases of the other types of racial crime - racism or discrimination. Penalties varied from 1 year of imprisonment with or without fine (respectively $30.6 \%$ and $14.2 \%$ of convictions) and between 1 to 2 years plus fine (22.5\%). In almost all convictions imprisonment sanctions were converted in alternative penalties.

In analyzing the convictions, it is important to note that in those cases that were finally classified as general disparagement (crime against individual honor) or contempt against public servant, although we had convictions, the racial nature of unlawful conduct was not considered - which happened in 15 cases (30.7\%).

The reasons to acquit were basically related to the lack of evidence in 30 cases; in 15 cases the Court understood that the act was not a criminal offense and in 2 cases it considered that the defendant was demonstrably not the author of the infraction. In 1 case, the decision was based on applying a custodial measure based on insanity, i.e. a recognition of the lack of understanding of the defendant.

The allegation of a lack of evidence refers to two types of problems; weak or contradictory testimonial proof regarding the fact or, as we will see below, a lack of proof of intention to discriminate. In the Brazilian criminal system, criminal conduct is punishable if practiced with intention or negligence. Intent is normally referred to as an individual's state of mind that directs her action, but some judges require in cases of racial crimes that besides the intention to act, the author should also demonstrate a special intent to discriminate.

Another group of noteworthy cases are those in which, despite the racist content of the insult, the Court recognized only simple disparagement, disregarding the racial content of the conflict and defining it only as a crime against personal honor. In order to explain the logic of such decisions, we have explored some of them below.

In one of the cases, in which the offender uttered the insult "shitty black" (negro de merda), although the accusation and the judge of first instance had classified the insult as racial disparagement, the Appeal Court re-graded it to simple disparagement affirming that the expression "shitty black" is as offensive as "shitty giant" (grandalhão de merda) or "shitty shrimp" (baixinho de merda), whereby the second element is only an indicator of the recipient of the insult. He stressed further that for this expression, "shitty black", to be recognized as racial disparagement it would be necessary for the word black to have a discriminatory and prejudiced connotation itself $f^{45}$.

In other cases of reclassification, the question of intent appears again. The Court requires specific proof of the intent of discriminating or offending an individual's race and ethnicity. The victim was offended by "nameless black girl" (preta sem nome), "I'm going to beat you, you black rascal" (vou te bater sua negra safada) and the Court

45 Criminal Appeal 48272000, São Paulo State Court. 
re-graded it to simple disparagement, stating that, although the pursuer has proven her allegations by means of witnesses, the evidence was made in relation to the insults, but not in consideration to the racial feature of the conduct. According to the decision, to prove the specific intent of racial insult it would be necessary to demonstrate by some means that the purpose of the offender was to offend the ethnicity of the pursuer ${ }^{46}$.

The need for proof of the specific intentional element is also the basis of many cases of acquittal. In a clear case of discrimination, the doormen of a nightclub made a condition that the offended would have to pay $\mathrm{R} \$ 10,00$, to enter the club claiming that because he was "black" he would have to pay, while other people who were accompanying the victim, all white, would not need to pay. The Court decided that the evidence collected was not sufficient for the conviction because there was no proof of racist motivation as the reason for discrimination suffered by the victim ${ }^{47}$. There was also the acquittal of a security guard of a prison who insulted a visitor with the expression "smelly black" (nego fedido), because, according to the decision, "there was no conscious and voluntary intent in committing racial discrimination, therefore, clearly, absent of the subjective element of intent ${ }^{\prime \prime 4}$.

If you compare these cases with the ones in which we had convictions, you notice that it is not possible to find a substantial difference in the dynamics of the facts or the offensiveness and seriousness of insults ${ }^{49}$. We were not able to identify any pattern for the recognition of racist intent in some cases and non-recognition in others. Recognizing discriminatory intent or not seems a rather arbitrary judicial decision with no clear reason.

The "heat of the discussion" is also often the cause for acquittal. In one case which reports an argument in a parking lot in which the offender utters phrases such as "you do not know who I am" (você não sabe quem sou eu), "it could only be because of your color, you should be in a cage" (só poderia ser da sua cor, você deveria estar numa jaula), "just look at me and this thing [referring to the victim] and you'll know who is right" (basta olhar para mim e pra essa coisa pra saber quem tem razão), the offender was convicted in first instance for simple disparagement and acquitted by the Court. The Court decision affirms that you cannot speak of the occurrence of the crime of disparagement when the expressions are uttered during the "heat of discussion" due to the absence

46 Criminal Appeal 2005.018057-8/0000-00, Mato Grosso do Sul State Court.

47 Criminal Appeal 70015082118, Rio Grande do Sul State Court.

48 Criminal Appeal 399.312-3/1-00, São Paulo State Court.

49 This second set of cases recognized as racial disparagement involved insults like: "you are black, go and fuck yourself, fuck off" (Criminal Appeal 990.09.112658-6, São Paulo State Court); (você é uma negra, vai pra puta que o pariu, vai tomar no cu); "dirty negro, black traitor, black thief, master at cheating, scumbag of syndicalism (negro sujo, neguinho pelego, negro ladrão, papa das falcatruas, escória do sindicalismo) (Criminal Appeal 70017372913, Rio Grande do Sul State Court), "black rascal" (nega safada) (Criminal Appeal 332.1772/4-00, São Paulo State Court). 
of the subjective element; "the parties were hot-headed" 50 . The fact that these insults occurred in a situation of "heated debate" and thus - according to the judges - lacked the intention to insult also causes acquittals in cases such as another case in which an offender uttered offensive words against the pursuer, calling her "a dirty black woman" (negra imunda), "black Macumba witch" (negra macumbeira), "thief" (ladrona) and "junk$\mathrm{ie}^{\prime \prime}$ (drogada), clearly revealing a certain prejudice of race and religion ${ }^{51}$. Yet in another case, the Court of the State of Sao Paulo acquitted the defendant, understanding that it was a melee between neighbors, with an exchange of insults in the heat of the moment because of a child whose kite fell into the neighbor's garden. Despite this, if we look at the words used by the offender we notice they were quite strong: "Go on you son of a bitch, you female monkey! You sons of bitches, fuck off, I want to see someone asking something from this race!" (vai sua filha da puta, sua macaca, bando de filha da puta, vai toma no cu, eu quero que alguém peça alguma coisa pra essa raça $)^{52}$. In the same sense, a woman was acquitted who, during a discussion between family members on father's day, used the expression "black pig" (negra porca) to refer to another person. The Court reasons that the case lacks criminal intent, because the parties involved had "feelings of unpleasantness" between one another. For the rapporteur judge, there was only an intention to hit back at the criticism made first by the victim ${ }^{53}$. Acting "under strong emotion" was also the ground of the decision which acquitted a woman who uttered the following offenses against a man: "you disgusting, grotty, black death... blacks should be in the Senzala (negro nojento, asqueroso, peste negra.../ugar de negro é na Senzala)" 54 .

The reasoning for this decisions was that the act was offending just the victim, with no racist intention, also led to acquittal in one case in which a cemetery manager said: "This group of blacks is not coming into the cemetery to do work"; "don't you know that blacks don't work in the evangelical cemetery". Accused of prejudice, the defendant was acquitted by the Court of Justice, who said that this "clearly exceeded in the language, he insulted the offended party", but there was not sufficient evidence of practicing the crime of racism - the disparagement would have been against the person of the victim only, without the intent of practicing prejudice against the black race. This line of reasoning sounds awkward if one pays attention to the content of the insults, especially when they show clear references not only to the individual victim, but also to the black community - "you, blacks", this "race", "this group of blacks". The reasoning of these decisions does not go further in explaining why these insults denote intent to offend only the individual victim.

50 Criminal Appeal 50902001, Rio de Janeiro State Court.

51 Criminal Appeal 483.151.3/3-0000-000,São Paulo State Court.

52 Criminal Appeal 990.09.358299-6, São Paulo State Court.

53 Criminal Appeal 418.769-3/2-00, São Paulo State Court.

54 Criminal Appeal 2003.050.04038, Rio de Janeiro State Court. 
The comments made by one of the judges, the one in the last case stated above, suggests that this outcome relates to the difficulty on the part of judges to recognize racial conflict in Brazilian society. This specific judge aligns the decision with the ideology of racial democracy: "this conduct practiced by the defendant is to be rejected since we live - we, as Brazilians - in a plural and multi-racial democratic society, where any form of discrimination is unacceptable. But we cannot confuse disparagement with the crime of racism ${ }^{55}$.

The case is also interesting due to the type of defense which is made. The defense claims that at the cemetery there is a black janitor as an employee and that the defendant is not racist because two of his witnesses are black. It is quite common in Brazil that people say they are not racist because they have black friends or relatives. Although the majority of people have discriminatory attitudes, it is difficult to hear someone admitting to be a racist ${ }^{56}$. Another facet of veiled racism.

In other cases, even if a joke is distasteful it is also recognized by the Court as not being a crime of racism. An example is the case where at a room in a health clinic, there was a patient, a doctor and a nurse. The doctor asked the patient to remove his shoes, for a more comprehensive examination. He did not want to, and opposed the request, claiming that he had dirty and "stinky" feet. The doctor said that there would not be any problem with the removal of his shoes, because there was no vulture in the room. The man then replied that there would be, insinuating that the nurse, a black woman, would be the vulture. The Court accepted that the offender's intention was not clear and that discrimination was not clear. The Court understood that the doctor started playing around, reminding him of the bird, and that the offender retorted with a distasteful joke. He was acquitted because the Court did not recognize the "more serious intention" of offending the victim ${ }^{57}$.

One case that had public repercussions involved a complaint against the singer Tiririca and the director of Sony Music due to the lyrics of one of his songs: "Look at her hair, it looks like steel wool to scour pans. When she passes by, it catches my attention. But her hair, it does its own thing. The stink almost knocked me out. Look, I can't stand your stench. Look at her hair" ${ }^{\prime \prime 8}$. The Court acquitted the defendant by stating that it was

\footnotetext{
55 Criminal Appeal 7001047910, Rio Grande do Sul State Court.

56 Research performed in the year 1995 by DataFolha and published in the largest Brazilian newspaper in circulation (Folha de S.Paulo) indicated that $89 \%$ of respondents consider that there is racism in Brazil, but only $10 \%$ acknowledge that they are racist.(http://almanaque.folha.uol.com.br/racismocordial.htm). In a new survey conducted in 2008 the data showed little variation: «open» prejudice is acknowledged by only $3 \%$ of the interviewees, but Brazilians continue to see themselves as a racist society. Ninety-one percent of white people are racist towards black people. See: O RACISMO confrontado. Folha de S. Paulo, São Paulo, 23 Nov. 2008. Available at: http://www1.folha.uol.com.br/fsp/especial/f2311200801.htm. Access: Nov. 01, 2019.

57 Criminal Appeal 327.399-2/5, São Paulo State Court.

58 "Veja os cabelo dela, parece bombril de arear panela. Quando ela passa, me chama atenção. Mas seus cabelo, não tem jeito não. A caatinga quase que me desmaiou. Olha eu não aguento o seu fedô. Veja os cabelos dela".
} 
clear in the proceedings that the singer had composed the music for his wife, "without the intention of offending anyone". In addition, "on reading the lyrics of the song you can see it is something of a joke, nothing serious, i.e., the defendant did not have the deliberate intention (direct intention) of practicing or inciting discrimination or prejudice based on color so the court does not perceive the existence of crime when the agent has no intention of discriminating". It also did not prove the underlying interest, of racist intent, by the executives of Sony Music in exploiting the work of Tiririca ${ }^{59}$.

\section{CONCLUSION: HOW COURTS FAIL TO RECOGNIZE BRAZILIAN RACISM}

Richard Delgado and Jean Stefancic speak of the existence of different forms of hate speech. Direct, indirect; covert, open; single or repetitive; sustained by authority and power or not; accompanied or not by threat or physical violence. It can be considered hate speech based on characteristics of the person or group to whom it is addressed, such as race, sex, sexual orientation, and origin. It may be differentiated according to who is speaking. It may be directed at an individual or a group. It can be verbal, written, disseminated on the internet, take the form of a flag, a symbol or a monument. It may be face-to-face or not or more or less virulent or harmful. Each of these variations may also require different regulations, occupy different positions in state responses maybe not all will come to be governed by criminal law. There is also the civil sphere and administrative law. There are cases that are not ruled at all ${ }^{60}$.

When we think about the construction of a public anti-racism policy, there is much to consider and to decide about what should be regulated and how. This is a process that starts in the law and is then transferred to the Judiciary - of the construction of categories and definitions, establishment of procedures and sanctions. All of these are choices. However, they must be considered. Although we have a long history of criticism of the anti-racism law and on how it has been enforced by the judiciary, the choices made by judges on their legal discourses and interpretations were not clear. The empirical research on court rulings made explicit the legal discourses underlying the decisions that ended up or justifying or condemning an act as racist.

In this article, our objective was to clarify aspects which seem in our opinion to be obscured in this relationship between the dynamics of Brazilian racism and the language of the legislator and the judge. The fact that we have a symbolically important statement in the Constitution that racism is intolerable in our society does not mean to say that, on being designed in detail, i.e. at the junction between the letter of the

\footnotetext{
59 Criminal Appeal 1069.98, Rio de Janeiro State Court.

60 DELGADO, Richard; STEFANCIC, Jean. Understanding words that wound. Boulder: Westview Press, 2004, p. 11.
} 
law and its interpretation by the judges, the anti-racism policy is not making a series of choices about what is recognized and what is simply neglected. When we understand these choices, it becomes easier to understand the dissatisfaction of the Black movement with the function of the law and locate the focal points of the problem.

On observing the history of anti-racism legislation, we see that legislation that defines racism as segregation or explicitly discriminatory treatment has not been able to understand the subtler and covert forms in which it is manifested in Brazil. Moreover, its first configuration did not understand the racial insult as one of the recurrent forms of racism. In legislative reform, almost ten years after the Federal Constitution, it was necessary to introduce among the crimes with racial motivation the racial disparagement, an exacerbated form of disparagement, with a stricter punishment, which extrapolates the effect of personal insult to recognize the offense to the entire racial group.

We have also seen that even after this legislative change, the results of the enforcement of the law by the judiciary are still fairly reticent. The result allows us to conclude the difficulty of the Courts acknowledging the existence of racism.

Among those cases that had overcome all of the filters of lower instances and had got to the Courts, we observed that most of them by decision of the Court, ended up not overcoming formal and procedural obstacles or were not recognized as crimes. These data without a doubt explains the criticism that cases of racism are not successfully won within the justice system.

Among the 200 cases analyzed, only in 31 was there recognition by the Judiciary of the existence of racist behavior. In the others, the narrative of the victim that there was an act of racism is not recognized by the justice system. This happened either through procedural terminations, or through merit decisions. In the latter group, we found that Courts disregarded the racial nature of the conflict by not recognizing intent of racial crime.

The express use of pejorative references to race or to black skin color does not seem to be sufficient for the courts to recognize the unlawful act offending the dignity of the group. In addition to the clear externalization of prejudice, they require unequivocal proof of the intention to practice discrimination. The Courts also tend not to see racism in cases of disagreements and arguments and when it is said jokingly, even though these episodes have been the trigger to externalize prejudice. Although the doctrine of criminal law requires declaration that an intentional crime has occurred, that the unlawful act is accompanied with proof of the intention of its practice, the requirement to prove, in addition to the intention of performing the action, the specific intention to discriminate. These are excessive demands. This understanding can be questioned, especially by requiring proof of something as abstract as the aim of discriminating or practicing prejudice. 
The doctrine of demanding proof of specific intent of being racist can also be criticized by being a very narrow interpretation of racism. Motive-centered doctrines have been criticized by placing a "very heavy, and often impossible, burden of proof" on the wrong side of the dispute; because the injury exists irrespective of the author's motives and motives are easy to hide and difficult to prove. It takes into account only the author's perspective - their motives - and not the harm suffered by the victim. And one very concrete output of this interpretation is that by requiring proof of the defendant's intent, the doctrine limits the number of individual conduct that the judicial system will deem as racially discriminatory ${ }^{61}$. This means that the Court is insensible to a large number of conduct that effectively puts more burden on one racial group - conduct that has discriminatory effects and can be effectively harmful to the victims, but are non-intentionally practiced by the author with the aim of being a racist.

Another challenge of our research was that the decisions on the absence of a subjective element were often not adequately justified, which means a lack of criterion for the enforcement of the law. The idea that you can prove somebody's intention is fiction in criminal law. What is going on inside someone's head is something unreachable unless externalized. Criminal law generally imputes a certain type of intention based on objective data from reality. The use of highly pejorative expressions associated with blacks, such as those we just described, was considered sufficient to demonstrate the prejudiced intention of the individual in a group of decisions and not in others. Racial intent was a recognized fact in several cases in which we identified convictions for racial disparagement. On the other hand, in an equally-significant number, we found others in which either the racial element is removed, leaving only the crime against personal honor, or the result is the acquittal. In all of these cases, the insults made explicit mention to race and color and we found no standard to differentiate between the cases in which the Courts recognize the discriminatory intent and the cases in which they did not recognize it. The same profile of cases can be considered by the Judiciary as practice or incitement of prejudice, racial disparagement, simple disparagement or an act without any illegality - without any criterion of interpretation being established.

What is required or not to prove intention is a criterion, which became loose and open, the criterion of each specific judge. It opens the margin to very distinct interpretations of the same facts, including judges that require something that is never made clear in order to recognize a racist intention. Judges conclude that there is no intention of practicing prejudice, but in most cases they do not justify what they would be expecting and why the evidence demonstrated and the insult that is undoubtedly racist in nature do not demonstrate racist intention. They seem to be expecting a more

61 See: LAWRENCE, Charles R. The id, the ego, and equal protection: Reckoning with unconscious racism. Stanford Law Review, v. 39, n. 2, p. 317-388, jan. 1987; ELY, John Hart. The centrality and myth of motivation analysis. San Diego Law Review, v. 15, n. 5, p. 1155-1162, aug. 1978. 
intense act of segregation, but that in any case it is not clear. When dealing with a subjective concept, of uncertain content, the lack of judicial parameters to define what is racist intent brings unsettling consequences to the rule of law. Excessive discretion opens space for bias and the situation is even more worrisome if we consider that the Brazilian judiciary is composed of $84.5 \%$ of white men, married and with children, with a medium age of 45 . Only $14 \%$ of the judges declared themselves as racially mixed ("pardos") and 1,4\% as blacks ${ }^{62}$.

Facing the results of our research, one of our interpretations is that the non-recognition of racist insult as a form of racism relates to the non-comprehension of its mechanism in the maintenance of racial hierarchies and of its violence.

The disregard of the severity of racial insult has as its premise, that its violence and severity are less than physical violence. This rationalization is at the basis of the racial democracy myth, which, in minimizing the intensity of the conflict, accommodates it in a structure that remains uneven. The "distasteful" joke, the insult that in substance had "no racist intention", the mere disagreement, the song that was only intended as satire, all these elements compose the type of racist manifestations plainly in force in Brazil but that are not recognized by the Judiciary as forms of racism. Acts of racism are naturalized by the dynamics of our hierarchical social relations and obscured by the justice system, which rarely emits declarations that such acts constitute unlawful acts and should not be tolerated. Judge's understanding of the law ends up not recognizing the dynamics of racism in Brazilian society and the importance of insult in the maintenance of social hierarchies.

While analyzing the motive-centered doctrine in the American Supreme Court, Charles Lawrence address one important effect of the adoption of this doctrine by the Courts: "the Court creates an imaginary world where discrimination does not exist unless it was consciously intended. And by acting as if this imaginary world was real and insisting that we participate in this fantasy, the Court and the law it promulgates subtly shape our perceptions of society"63.

We think in the legitimizing role legal discourse can have in justifying social order, it is possible to see a perverse alliance between subtle social practices of racism and judicial practices that reduce their importance and favor invisibility and denial. Even though we need not depend on the justice system to break down the invisibility of racism, from the moment that we - as a political community- bet on the strategy of creating laws, we have the expectation and give the legal system authority to decide what

62 CNJ - Conselho Nacional de Justiça. Censo do Poder Judiciário: Vetores Iniciais e Dados Estatísticos (VIDE). Brasília: Departamento de Pesquisas Judiciárias do CNJ, 2014. Available on: https://www.cnj.jus.br/wp-content/uploads/2011/02/CensoJudiciario.final.pdf. Access: Nov. 05, 2019.

63 LAWRENCE, Charles R. The id, the ego, and equal protection: Reckoning with unconscious racism. Stanford Law Review, v. 39, n. 2, p. 317-388, jan. 1987, p. 325. 
is legal or illegal, tolerated or not tolerated, harmful or harmless. However, the justice system functions to produce and mask or denying racism, and this seems to us an important piece of the puzzle in the reproduction of the ideology of racial democracy.

\section{REFERENCES}

BANTON, Michael; MILES, Robert. Racism. In: CASHMORE, Ellis. Dictionary of Race and Ethnic Relations. 3. ed. London/New York: Routledge, 1994.

BASTIDE, Roger; FERNANDES, Florestan. Relações raciais entre negros e brancos em São Paulo. São Paulo: Editora Anhembi, 1955.

BUTLER, Judith. Excitable Speech: A politics of the performative. New York, London: Routledge, 1997.

CARDOSO, Hamilton. Isso é conversa de branco. Lua Nova: Revista de Cultura e Política, São Paulo, v. 2, n. 3, p. 13-19, dec.1985. Available at: http://www.scielo.br/scielo.php?pid=S0102-6445 1985000400003\&script=sci_arttext\&tlng=pt. Access: Nov. 05, 2019.

CARNEIRO, Sueli; CORRÊA, Sônia; ADORNO, Sérgio; OLIVEIRA, Eduardo H. P. de. Racismo e Discriminação. Cadernos de Pesquisa - Novas Faces da Cidadania: Identidades Políticas e Estratégias Culturais, São Paulo, n. 4, p. 59-95, Jun. 1996. Available at: http://bibliotecavirtual.cebrap.org.br/ arquivos/racismo_e_discriminacao_e.pdf. Access: Nov. 05, 2019.

CNJ - Conselho Nacional de Justiça. Censo do Poder Judiciário: Vetores Iniciais e Dados Estatísticos (VIDE). Brasília: Departamento de Pesquisas Judiciárias do CNJ, 2014. Available on: https:// www.cnj.jus.br/wp-content/uploads/2011/02/CensoJudiciario.final.pdf. Access: Nov. 05, 2019.

DELGADO, Richard; STEFANCIC, Jean. Understanding words that wound. Boulder: Westview Press, 2004.

ELY, John Hart. The centrality and myth of motivation analysis. San Diego Law Review, v. 15, n. 5, p. 1155-1162, aug. 1978. Available at: https://digital.sandiego.edu/sdlr/vol15/iss5/8/. Access: Nov 05, 2019.

FERNANDES, Florestan. A integração do negro na sociedade de classes. São Paulo: Cia. Editora Nacional, 1965.

FREYRE, Gilberto. Casa Grande e Senzala: formação da família brasileira sob o regime da economia patriarcal. 29 ed. Rio de Janeiro: Record, 1994.

FULLIN, Carmen Silvia. A criminalização do racismo: dilemas e perspectivas. 1999. Dissertação (mestrado em Sociologia) - FFLCH, Universidade de São Paulo, São Paulo, 1999. Available at: https://bdpi.usp.br/item/001039299. Access: Nov. 05, 2019.

FULLIN, Carmen Silvia. Direito e Racismo: Observações sobre o alcance da legislação penal antidiscriminatória no Brasil. Revista da Faculdade de Direito de São Bernardo do Campo, São 
Bernardo do Campo, v. 6, n. 2, p. 21-35, 2000. Available at: https://revistas.direitosbc.br/index.php/ fdsbc/article/view/538. Access: Nov. 05, 2019.

ERVING, Goffman. Stigma: Notes on the management of spoiled identity. New York: Simon \& Schuster Inc, 1963.

GUIMARÃES, Antonio Sérgio Alfredo. O insulto racial: as ofensas verbais registradas em queixas de discriminação. Estud. afro-asiát., Rio de Janeiro, n. 38, p. 31-48, Dec. 2000. Available at: http:// www.scielo.br/scielo.php?script=sci_arttext\&pid=S0101-546X2000000200002\&lng =en\&nrm=iso. Access: Nov 05, 2019.

GUIMARÃES, Antonio Sérgio Alfredo. Preconceito e discriminação: queixas de ofensas e tratamento desigual dos negros no Brasil. 2 ed. Editora 34, 2004.

GUIMARÃES, Antonio Sérgio Alfredo. Racismo e anti-racismo no Brasil. 1997. Tese (livre docência em sociologia) - FFLCH, Universidade de São Paulo, São Paulo, 1997.

LAMONT, Michèle et al. Getting respect: responding to stigma and discrimination in the United States, Brazil and Israel. New Jersey: Princeton University Press, 2017.

LAWRENCE, Charles R. The id, the ego, and equal protection: Reckoning with unconscious racism. Stanford Law Review, v. 39, n. 2, p. 317-388, jan. 1987. Available at: www.jstor.org/stable/1228797. Access: Nov. 05, 2019.

LIMA, Marcia. Desigualdades raciais e políticas públicas: ações afirmativas no governo Lula. Novos Estudos CEBRAP, São Paulo, n. 87, p. 77-95, jul. 2010. Available at: http://www.scielo.br/scielo. php?pid=S0101-33002010000200005\&script=sci_arttext. Access: Nov. 05, 2019.

LIMA, Márcia. Serviço de branco, serviço de preto: um estudo sobre cor e trabalho no Brasil urbano. 2001. Tese (doutorado em sociologia) - Programa de Pós-graduação em Sociologia e Antropologia, IFCS-UFRJ, Rio de Janeiro, 2001.

LIPPMANN, Walter. Public opinion. New York: Harcourt, 1922.

MACHADO, Marta Rodriguez de Assis; FERREIRA, Carolina Cutrupi e SANTOS, Natália Neris da Silva. Legislação antirracista punitiva no Brasil: Uma aproximação à aplicação do direito pelos Tribunais de Justiça brasileiros. Revista de Estudos Empíricos em Direito, vol. 2, n 1, p. 60-92, 2015.

MITCHELL-WALTHOUR, Gladys. The Politics of Blackness: Racial Identity and Political Behavior in Contemporary Brazil. New York: Cambridge University Press, 2018.

NASCIMENTO, Abdias do. Combate ao racismo: discursos e projetos. Brasília: Coordenação de Publicações Câmara de Deputados, 1983.

NOGUEIRA, Oracy. Tanto preto quanto branco: estudo de relações raciais. São Paulo: T.A. Queiroz, 1985. 
SANTOS, Ivair Augusto dos. Racismo no Brasil não é criminalizado. [Entrevista cedida a] Luciana Abade. Jornal do Brasil, Brasília, 30 sep. 2009. Available on: https://revistaforum.com.br/blogs/ mariafro/bmariafro-ivair-augusto-dos-santos-racismo-no-brasil-nao-e-criminalizado/ Access: Nov. 05, 2019.

O RACISMO confrontado. Folha de S. Paulo, São Paulo, 23 nov. 2008. Available at: http://www1. folha.uol.com.br/fsp/especial/fj2311200801.htm. Access: Nov. 01, 2019.

O RACISMO minimizado. Correio Braziliense, Opinião, p. 20, 13 oct. 2009. Available on: https:// www2.senado.leg.br/bdsf/bitstream/handle/id/43505/noticia.htm? sequence=1\&isAllowed=y Access: Nov. 05, 2019.

SANTOS, Natália Neris da Silva. A voz e a palavra do Movimento Negro na Assembleia Nacional Constituinte (1987/1988): Um estudo das demandas por direitos. 2015. Dissertação (Mestrado em Direito) - Escola de Direito da Fundação Getulio Vargas, São Paulo, 2015. Available on: https:// bibliotecadigital.fgv.br/dspace/bitstream/handle/10438/13699/Disserta\%C3\%A7\%C3\%A3o_Nat\%C3\%A1 lia\%20Neris.pdf?sequence=1\&isAllowed=y. Access: Nov. 05, 2019.

SILVA JÚNIOR, Hédio. A política de inclusão do negro é a penal. [Entrevista concedida a] Fernanda da Escóssia. Folha de S. Paulo, São Paulo, 09 jul. 2001. Available on: https://www1.folha.uol.com. br/fsp/brasil/fc0907200113.htm. . Access: Nov. 05, 2019.

SILVA JÚNIOR, Hédio. Quando a lei não sai do papel. [Entrevista concedida a] Andréa Barros. Época, Rio de Janeiro, 13 dec. 2010. Available on: http://revistaepoca.globo.com/Revista/Epoca/0,„EMI193501-15518,00.html. Access: Nov. 05, 2019. 